Original Research Paper

\title{
Pemberdayaan Masyarakat melalui Pengembangan Usaha Budidaya Madu Trigona untuk Membentuk Kampong Madu Desa Saribaye Kecamatan Lingsar
}

\author{
Embun Suryani ${ }^{1}$, Sri Wahyulina ${ }^{2}$, Diswandi ${ }^{3}$, L. M. Furkan ${ }^{4}$, Serifudin Serif ${ }^{5}$, M. Ali ${ }^{6}$ \\ ${ }^{1}$ Fakultas Ekonomi dan Bisnis, Universitas Mataram, Mataram,Indonesia; \\ ${ }^{2}$ Fakultas Ekonomi dan Bisnis, Universitas Mataram, Mataram,Indonesia \\ ${ }^{3}$ Fakultas Ekonomi dan Bisnis, Universitas Mataram, Mataram,Indonesia; \\ ${ }^{4}$ Fakultas Ekonomi dan Bisnis, Universitas Mataram, Mataram,Indonesia; \\ ${ }^{5}$ Fakultas Ekonomi dan Bisnis, Universitas Mataram, Mataram,Indonesia; \\ ${ }^{6}$ Fakultas Peternakan, Universitas Mataram, Mataram,Indonesia.
}

DOI: https://doi.org/10.29303/jpmpi.v4i2.810

Sitasi: Suryani, E., Wahyulina, S., Diswandi., Furkan, L. M., Serif, S., \& Ali, M. (2021). Pemberdayaan Masyarakat melalui Pengembangan Usaha Budidaya Madu Trigona untuk Membentuk Kampong Madu Desa Saribaye Kecamatan Lingsar. Jurnal Pengabdian Magister Pendidikan IPA, 4(2)

\section{Article history}

Received: 29 Maret 2021

Revised: 29 Mei 2021

Accepted: 25 Juni 2021

*Corresponding Author: Embun Suryani, Universitas Mataram, Mataram, Indonesia Email:

embunsuryani@unram.ac.id
Abstract: Desa Saribaye merupakan desa dengan cakupan wilayah berupa lahan pertanian, perkebunan dan kawasan hutan rakyat yang cukup luas, sehingga memiliki potensi yang besar untuk mengembangkan budidaya lebah madu trigona. Budidaya lebah madu trigona dan produk-produk turunannya merupakan salah satu upaya untuk memberdayakan masyarakat yang berbasis ekonomi kreatif, yang diharapkan dapat berkontribusi dalam meningkatkan pendapatan masyarakat. Kegiatan ini bertujuan untuk mengembangkan budidaya madu trigona dengan manajemen usaha yang professional, dengan menginisiasi terbentuknya "Kampung Madu Trigona" untuk mendukung Desa Saribaye sebagai salah satu destinasi agroekowisata di Pulau Lombok. Untuk mencapai tujuan tersebut, model pendekatan yang digunakan adalah Participatory Rural Appraisal (PRA) yang menekankan keterlibatan masyarakat dalam keseluruhan kegiatan mulai dari perencanaan, pelaksanaan dan evaluasi program. Kegiatan ini terdiri dari tiga kegiatan yaitu penyuluhan, demplot (demonstration plot), dan pendampingan budidaya madu trigona. Kelompok sasaran dari kegiatan ini yaitu Kelompok Usaha Madu Sakti dan Kelompok Karang Taruna. Hasil dan luaran kegiatan setelah dilaksanakan sosialisasi dan pelatihan adalah masyarakat sasaran mengalami peningkatan pemahaman dan ketrampilan untuk melakukan budidaya madu trigona dan membuat kemasan yang menarik dan hygienis. Melalui budidaya madu trigona ini dapat meningkatkan pendapatan masyarakat sasaran yang diharapkan akan menggerakkan seluruh anggota masyarakat desa, sehingga dapat meningkatkan perekonomian Desa Saribaye. Oleh karena itu, dengan dilaksanakannya kegiatam PKM ini maka terjadi peningkatan dan perbaikan kemampuan dan ketrampilan masyarakat sasaran yang mendukung terjadinya peningkatan kegiatan ekonomis masyarakat. Diharapkan melalui kegiatan ini dapat menumbuhkan ide-ide kreatif, untuk mendapatkan hasil yang lebih baik dan lebih bervariasi yang kemudian dapat dijadikan modal awal untuk memulai usaha.

Keywords: Ekonomi Kreatif; Madu Trigona; Kampong Madu; Agrowisata 


\section{Pendahuluan}

Kecamatan Lingsar dengan luas wilayah $96,58 \mathrm{~km}^{2}$ yang memiliki potensi di bidang pertanian dan perkebunan karena lebih dari $50 \%$ wilayah Kecamatan Lingsar merupakan kawasan pertanian dan perkebunan yang ditanami dengan tanaman buah-buahan seperi tanaman Manggis, rambutan dan mangga terdapat hampir diseluruh wilayah. Hal ini didukung oleh karakteristik struktur perekonomian Kecamatan Lingsar masih bercorak agraris yang menunjukkan bahwa masyarakat mengolah dan menggunakan sawah secara optimal sebagai mata pencaharian.

Desa Saribaye merupakan salah satu desa dari 15 (lima belas) desa di Kecamatan Lingsar Kabupaten Lombok Barat. Desa ini merupakan salah satu desa perluasan bersama dengan Desa Gontoran. Luas wilayah Desa Saribaye hanya sekitar $1,73 \mathrm{~km}^{2}$ atau sekitar $1,79 \%$ dari luas Kecamatan Lingsar yang sebesar $96,58 \mathrm{~km}^{2}$. Secara administrasi Desa Saribaye terdiri dari 5 dusun, yaitu Dusun Sandongan Timur, Dusun Sandongan, Dusun Presak, Dusun Repok Keri, dan Dusun Nirbaye. Desa Saribaye terletak $1 \mathrm{~km}$ dari Ibu Kota Kecamatan dan $22 \mathrm{~km}$ dari ibukota Kabupaten ditempuh dalam waktu 36 menit dan jarak dari Ibu Kota Propinsi adalah $12 \mathrm{~km}$ ditempuh dalam waktu 23 menit dengan menggunakan kendaraan bermotor. Infrastruktur menuju Desa Saribaye sangat baik dengan kondisi jalan yang telah diaspal (hotmix). Kondisi infrastuktur di Desa Saribaye juga sudah cukup baik, dari $8 \mathrm{~km}$ jalan, hanya 36\% saja yang belum diaspal. Selain itu, mayoritas rumah tangga di desa ini juga sudah mendapatkan aliran listrik yaitu sekitar $84 \%$ dari total rumah tangga di Desa Saribaye. Namun demikian, kondisi penduduk dilihat dari mata pencaharian dan kesejahteraannya masih tergolong memprihatinkan. Jumlah penduduk yang tidak bekerja cukup besar yaitu sekitar $10 \%$ dari jumlah penduduk yang tergolong angkatan kerja. Selain itu, jumlah penduduk yang bekerja sebagai buruh tani dan buruh ternak menunjukkan angka yang tinggi sekitar $45 \%$ dari total angkatan kerja. Pekerjaan sebagai buruh tidak memberikan jaminan untuk memperoleh pedapatan yang cukup untuk memenuhi kebutuhan hidupnya. Kondisi ini terlihat dari jumlah KK di Desa Saribaye yang tergolong prasejahtera dan sejahtera 1 juga cukup tinggi yaitu sebesar 23\%, sedangkan sebagian besar keluarga
(51\%) tergolong sebagai keluarga sejahtera 2 dan sisanya sebesar $26 \%$ tergolong keluarga sejahtera 3 .

Desa Saribaye memiliki potensi dibidang pertanian, perikanan, perdagangan dan industri rumah tangga. Lahan pertanian di Desa Saribaye cukup luas, namun kepemilikan lahan tersebut hanya dimiliki oleh segelintir masyarkat Desa Saribaye, sebagian besar lahan pertanian di desa ini dimiliki oleh masyarakat yang bukan penduduk Desa Saribaye, bahkan banyak dimiliki oleh penduduk Kota. Dari $736 \mathrm{KK}$ yang ada di Desa Saribaye, hanya 102 KK $(13,9 \%)$ yang memiliki lahan yang cukup luas, sebagian besar masyarakat hanya memiliki lahan yang sempit sebagai tempat tinggal. Hal ini menyebabkan lokasi pemukiman di Desa Saribaye sangat sempit dan berhimpitan. Kondisi ini sangat ironis, dengan potensi sumberdaya alam yang begitu besar namun tidak dapat dinikmati secara optimal oleh seluruh masyarakat.

Dibalik semua permasalahan tersebut, Desa Saribaye merupakan desa yang memiliki potensi alam, lingkungan dan budaya yang sangat penting untuk mendukung dikembangkannya Agrowisata. Slogan Back to Nature mendorong terjadinya perubahan preferensi wisatawan global maupun domestik terhadap semakin tingginya permintaan terhadap wisata alam. Preferensi wisatawan berkembang secara dinamis, dimana kecenderungan pemenuhan kebutuhan dalam bentuk menikmati obyek-obyek spesifik seperti udara segar, pemandangan yang indah dan hijau, pengolahan produk secara tradisional, maupun produk-produk pertanian modern dan spesifik menunjukkan peningkatan yang pesat (Pamulardi, 2006). Sentra agrowisata belakangan ini banyak diminati oleh wisatawan asing dan lokal yang setiap tahun jumlahnya terus bertambah. Disamping itu sentra agrowisata merupakan tujuan wisata alternatif yang menyajikan berbagai pengalaman unik, menarik dan dengan harga yang relatif lebih murah dibanding tujuan wisata lainnya.

Selain itu, Kecamatan Lingsar, tidak terkecuali Desa Saribaye, merupakan kawasan pertanian dan perkebunan yang ditanami dengan tanaman buah-buahan seperti tanaman manggis, rambutan dan mangga terdapat hampir diseluruh wilayah. Kondisi ini menyebabkan Desa Saribaye memiliki potensi yang besar untuk mengembangkan budidaya lebah madu trigona, karena berada di daerah pinggiran hutan dengan 
vegetasi tanaman bunga, buah dan kayu yang berlimpah sebagai sumber pakan lebah. Lebah merupakan salah satu Hasil Hutan Bukan Kayu (HHBK). Potensi yang besar ini harus didukung oleh pemanfaatan yang optimal dan lestari. Hal ini juga akan memberikan manfaat terhadap peningkatan ekspor madu Indonesia serta peningkatan kesejahteraan dan pendapatan masyarakat (Yuni, et.al., 2018). Lebah madu merupakan kelompok serangga yang berperan sebagai agen polinator tanaman berbunga, sehingga dapat meningkatkan produksi tanaman tersebut (Corlett, 2011). Sedangkan, lebah madu trigona (Trigona sp.) merupakan jenis lebah yang tidak menyengat dan merupakan lebah tertua yang pernah diketahui (Sihombing, 2005). Produksi nasional madu yang saat ini diperkirakan 8.800 ton, jumlah ini masih jauh dari kebutuhan yang semestinya sekitar 25.000 ton per tahun (Novandra dan Widnyana, 2013). Target untuk dapat mengeksport madu untuk menghasilkan devisa masih jauh dari jangkauan, karena untuk kebutuhan dalam negeri saja belum terpenuhi.

Saat ini, lebah madu trigona dibudidaya oleh masyarakat Desa Lingsar hanya dalam skala kecil, sehingga belum bisa memberikan manfaat ekonomis bagi masyarakat. Hal ini disebabkan karena kurangnya pengetahuan masyarakat Desa Saribaye tentang tata cara budidaya madu trigona yang benar. Selain itu, masyarakat juga memiliki kemampuan yang sangat terbatas untuk mengemas dan mengolah produk turunan madu trigona. Implikasinya adalah potensi yang besar tersebut belum mampu dikelola secara optimal untuk meningkatkan kesejahteraan masyarakat Desa Saribaye.

Lebih lanjut, untuk mengembangkan ekonomi kreatif masyarakat maka segala kegiatan ekonomis masyarakat desa harus dikelola secara professional dengan membentuk suatu wadah untuk mengelola potensi spesifik desa. Badan Usaha Milik Desa (BUMDes) merupakan salah satu wadah yang dapat digunakan untuk mencapai target di atas. BUMDes adalah badan usaha yang seluruh atau sebagian besar modalnya dimiliki oleh desa melalui penyertaan langsung yang berasal dari kekayaan desa yang dipisahkan guna mengelola aset, jasa pelayanan, dan usaha lain untuk sebesarbesarnya kesejahteraan masyarakat desa. Pengelolaan BUMDes sepenuhnya dilaksanakan oleh masyarakat desa, yaitu dari desa, oleh desa, dan untuk desa (Zulkarnaen, 2016). Karena itu, melalui pengembangan dan penguatan Bumdes, potensi desa bisa dioptimalkan untuk menuju desa wirausaha yang mampu menggerakkan perekonomian dan menyediakan lapangan kerja bagi seluruh lapisan masyarakat. Pemerintah Desa Saribaye telah menginisiasi terbentuknya BUMDes "Pintu Rizqi" Desa Saribaye berdasarkan Peraturan Desa Nomor: 11 Tahun 2016 tentang Badan Usaha Milik Desa (BUMDes). Penyertaan Modal untuk BUMDes "Pintu Rizqi”" sebesar Rp. 7.500.000,dan saat ini hanya mengelola Perkumpulan Pemakai Air Bersih (P2AB). Hal ini menunjukkan bahwa pengelolaan BUMDes "Pintu Rizqi" belum dilakukan secara optimal untuk mendukung kegiatan ekonomi kreatif masyarakat Desa Saribaye. Untuk itu, melalui kegiatan ini akan dikembangkan usaha budidaya lebah madu trigona dalam skala besar dengan manajemen usaha yang professional. Mengingat sebagian besar masyarakat Desa Saribaye tidak memiliki lahan yang luas untuk menanam buah-buahan, maka akan diinisiasi terbentuknya "Kampung Madu Trigona Desa Saribaye" sebagai bentuk pendekatan holistik dan berkelanjutan berbasis hasil-hasil riset multidisiplin untuk mendukung Desa Saribaye sebagai salah satu destinasi agroekowisata di Pulau Lombok. "Kampong Madu Desa Saribaye" akan dikembangkan di Hutan Irup milik Desa Saribaye, sehingga seluruh masyarakat Desa Saribaye dapat melakukan budidaya madu trigona secara berkelompok dengan dikoordinir oleh BUMDes Pintu Rezki Desa Saribaye. Budidaya lebah madu trigona dan produk-produk turunannya merupakan salah satu upaya untuk memberdayakan masyarakat yang berbasis ekonomi kreatif. Kegiatan ini diharapkan akan mampu meningkatkan ketrampilan dan keberdayaan masyarakat, sehingga sejalan dengan program pemerintah desa yang cukup menekankan pada kegiatan pembinaan dan pemberdayaan masyarakat, yang ditunjukkan oleh 25\% dana APBDes dialokasi untuk kedua kegiatan tersebut. Selanjutnya, diharapkan Desa Saribaye ini menjadi model science-technopark Universitas Mataram di bidang pengelolaan ekonomi kreatif melalui budidaya madu trigona dan pengembangan agrowisata berbasis kearifan lokal yang berkelanjutan. Kelompok masyarakat yang menjadi sasaran dari kegiatan ini adalah Kelompok Usaha Madu Sakti dan Kelompok Karang Taruna Desa Saribaye. 


\section{Metode}

Berdasarkan solusi atas permasalahan prioritas desa dan untuk mewujudkan ekonomi kreatif melalui pengembangan usaha pengolahan abon ikan Nila di Desa Saribaye, maka kegiatan ini akan dilakukan melalui pendekatan Participatory Rural Appraisal (PRA) Community development. Kedua pendekatan ini menekankan keterlibatan masyarakat secara langsung sebagai subyek dan obyek dalam pelaksanaan keseluruhan kegiatan mulai dari perencanaan, pelaksanaan dan evaluasi program kegiatan. Sedangkan metode yang digunakan untuk melaksanakan kegiatan ini adalah Kaji Tindak Partisipatif melalui pelatihan, pembelajaran, Demonstration plot (Demplot), dan pendampingan secara berkelanjutan dan berkolaborasi dengan kelompok sasaran.

\section{Hasil dan Pembahasan}

\section{Demplot Budidaya Madu Trigona}

Madu trigona merupakan potensi unggulan yang sangat penting yang dimiliki oleh Desa Saribaye, karena didukung oleh potensi hasil perkebunan buah-buahan yang melimpah. Tanaman buah-buahan ini merupakan sumber pakan utama bagi lebah madu trigona. Pada masa pandemik covid19 produk madu trigona menjadi sangat diminati oleh masyarakat karena dipercaya khasiatnya untuk menjaga stamina tubuh agar terhindar dari penularan covid19. Produk madu trigona juga dapat menjadi produk khas Desa Saribaye dan memiliki nilai jual sangat tinggi, harga per botol mencapai Rp. 250.000. Untuk itu, dalam kegiatan ini dilakukan penguatan kelompok lebah madu trigona dengan memberikan stimulan berupa tambahan koloni madu trigona dan pengemasan yang memenuhi standar kelayakan higienitas.

Kelompok Madu Sakti diberikan pelatihan bagaimana: 1) meningkatkan jumlah setup lebah madu trigona dengan mencari koloni di alam serta memisahkan koloni; 2) melakukan budidaya tanaman buah dan bunga sebagai sumber pakan lebah madu trigona; 3) melakukan diversifikasi sumber pendapatan dengan tidak hanya menjual produk madu tapi juga menjual setup lebah trigona; dan 4) memasukkan unsur agroeduwisata dalam budidaya lebah madu trigona. Gambar 1 menunjukkan rak/rumah lebah madu trigona yang telah dibuat bersama KU. Madu Sakti dan kelompok My Darling. Rak/rumah lebah madu trigona dipusatkan di Kantor Desa Saribaye, karena mudah diakses oleh wisatawan. Saat ini telah dibuat 3 buah rak/rumah lebah madu trigona yang bisa menampung lebih dari 50 setup.
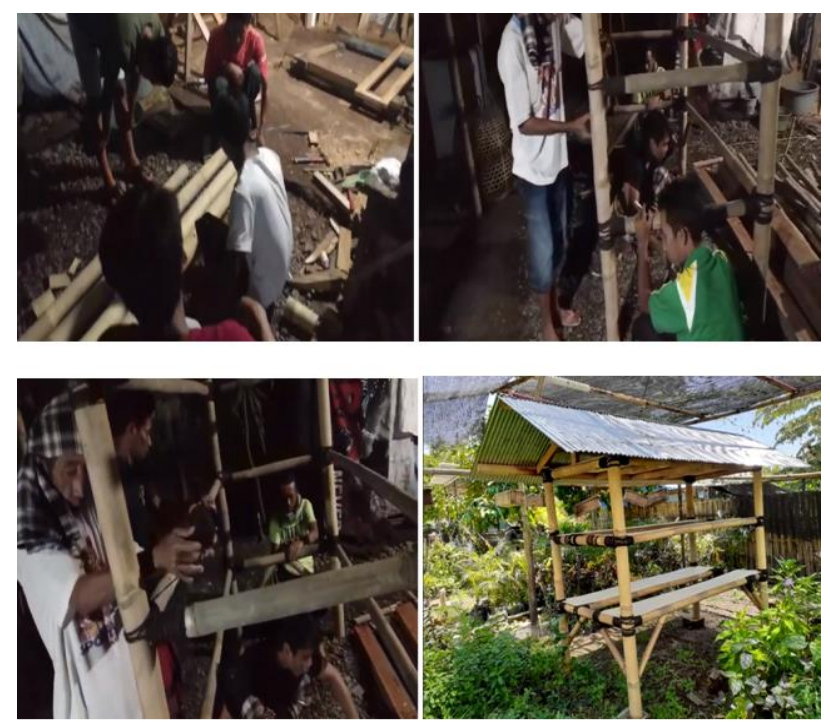

Gambar 1. Demplot pembuatan rak/rumah setup lebah madu trigona bersama KU. Madu Sakti dan Kelompok My Darling

Budidaya madu trigona juga memiliki potensi yang sangat besar untuk dijadikan sebagai salah satu atraksi wisata. Atraksi wisata tersebut dapat berupa panen madu yang langsung dapat dilakukan oleh wisatawan. Pada masa pandemik ini, sektor wisata merupakan sektor yang paling terdampak negatif, hampir tidak ada wisatawan yang berkunjung ke destinasi-destinasi wisata. Untuk itu pada kesempatan ini, KU. Madu Sakti diberi bantuan untuk mempersiapkan diri secara optimal, agar pada saat pandemi berlalu, KU. Madu Sakti siap menerima kunjungan wisatawan. Pada awal bulan Juli, dilakukan demplot pembuatan rak/rumah setup lebah madu trigona dengan berbahan bambu. Bambu merupakan bahan baku yang memiliki nilai estitika sehingga disukai oleh wisatawan. Desa Saribaye juga banyak menghasilkan bambu yang dapat digunakan untuk berbagai keperluan. Demplot pembuatan rak/rumah setup lebah madu trigona nampak pada Gambar 2 dan Gambar 3 di bawah ini. 

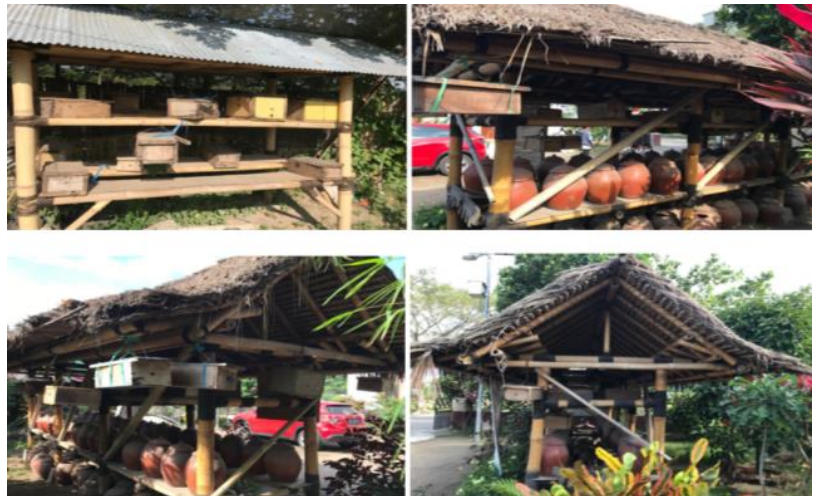

Gambar 2 Setup madu trigonayang disusun di atas rak bambu memiliki nilai estitika
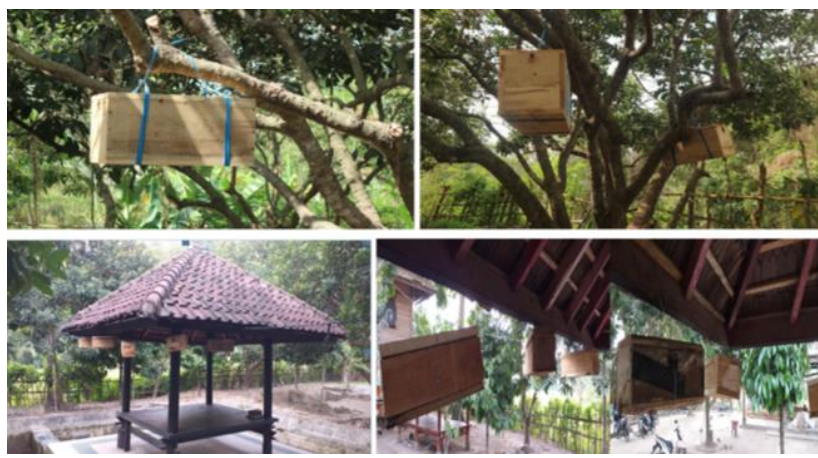

Gambar 3 Setup madu trigona yang disusun di berugak dan pohon-pohon buah

\section{Budidaya Tanaman Bunga sebagai Sumber Pakan}

Melakukan budidaya tanaman buah (tabulampot) dan bunga sebagai sumber pakan madu trigona yang sekaligus bisa menjadi atraksi wisata dan sumber pendapatan lain. Tanaman bunga yang saat ini dikembangkan adalah taman bunga gumitir, bunga matahari, dan bunga kenikir. Taman bunga gumitir ini dibudidaya di lahan milik Desa Saribaye dan merupakan salah satu sumber pendapatan desa dan dikelola oleh BUMDes. Produksi bunga gumitir dapat dijual dengan harga jual berkisar antara 12.000 sampai 60.000 rupiah, dimana panen dilakukan setiap minggu dengan hasil panen berkisar antara 1-2 kwintal per minggu. Selain itu, taman bunga ini juga dapat sebagai spot photo bagi atraksi wisata. Gambar 4 berikut ini menunjukkan taman bunga yang dibudidaya.
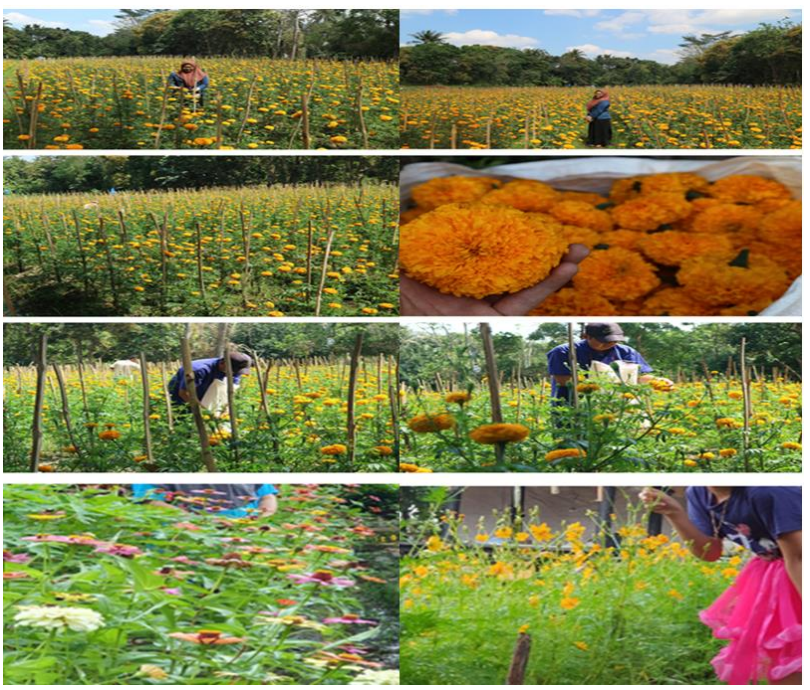

Gambar 4. Budidaya Tanaman Bunga sebagai Sumber

Pakan Madu Trigona yang sekaligus menjadi atraksi wisata

\section{Proses Pemanenan dan Pengemasan Madu Trigona}

Pemanenan dan pengemasan madu trigona menjadi sangat penting agar madu trigona tersebut layak dan memiliki nilai jual yang tinggi. Kelompok sasaran dilatih bagaimana melakukan proses pemanenan dan mengemas dengan kemsan yang hygienis dan menarik. Gambar berikut menunjukkan proses pemanenan dan pengemasan madu trigona. Pengemasan madu trigona merupakan langkah terakhir yang sangat penting agar madu trigona yang dihasilkan memiliki daya jual yang tinggi. Gambar 5 berikut merupakan kegiatan pemanenan dan pengemasan madu trigona.

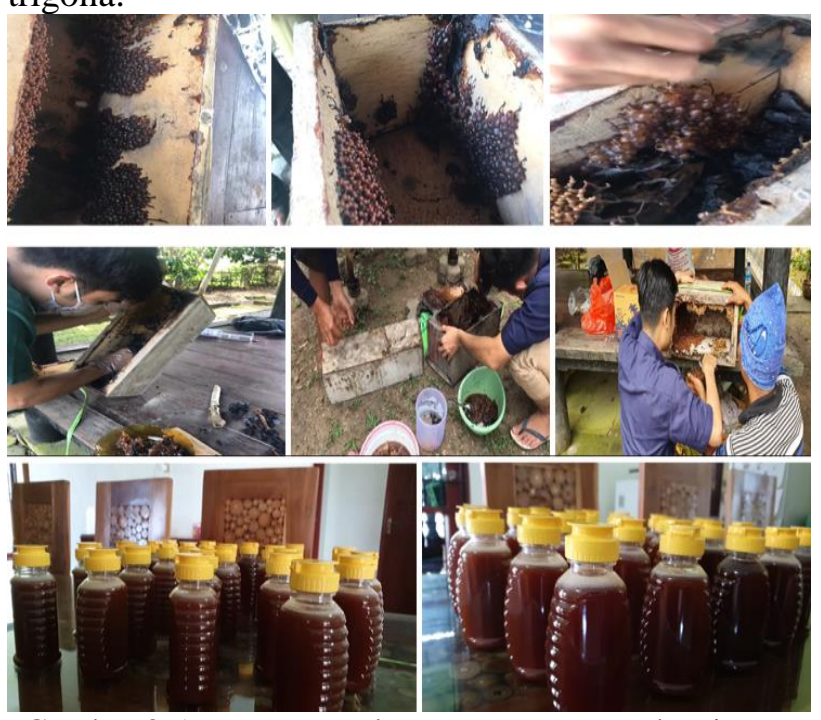

Gambar 3.5 Pemanenan dan pengemasan madu trigona 


\section{Pendampingan Usaha}

Pendampingan budidaya madu trigona dilakukan di Desa Saribaye. Pendampingan secara berkelanjutan dilakukan dengan tetap melakukan komunikasi dengan peserta apabila memiliki permasalahan yang ingin didiskusikan. Hal ini dilakukan sehingga bisa memberikan manfaat yang besar bagi masyarakat khususnya kelompok usaha madu trigona di Desa Saribaye. Pendampingan manajemen usaha dan pembukuan sederhana juga dilakukan sebagai bekal peserta untuk memulai usahanya.

\section{Kesimpulan}

1. Secara keseluruhan kegiatan pengembangan budidaya madu trigona melalui pelatihan masyarakat berjalan baik dan lancar. Dampak pelatihan memberikan bekal keterampilan melakukan budidaya madu trigona, meningkatkan kapasitas produksi, proses pemanenan, sampai tahap pengemasan, sehingga produk madu trigona yang dihasilkan memiliki nilai jual yang tinggi. Berbagai materi yang telah diberikan, termasuk manajemen usaha, diharapkan akan membantu memudahkan proses produksi, dan diharapkan dapat berkelanjutan sebagai usaha masyarakat desa.

2. Setelah menerima bantuan berupa penambahan stimulant berupa setup madu trigona sebanyak 60 unit, kelompok Madu Sakti sebagai kelompok sasaran bisa meningkatkan produksinya. Semula, kelompok ini hanya mampu menghasilkan 7 botol sekali panen, sekarang sudah mencapai 15 botol sekali panen.

3. Dengan dikuasainya sejumlah ketrampilan oleh peserta pelatihan akan berdampak juga pada pertumbuhan industri kecil di desa guna peningkatan taraf ekonomi penduduk desa.

\section{Saran}

1. Potensi budidaya madu trigona untuk meningkatkan perekonomian masyarakat Desa Saribaye sangat besar. Untuk itu pemerintah desa harus lebih optimal dan menambahkan sektor ini ke dalam salah satu sektor yang mendapat dukungan untuk pengembangannya.

2. Pemerintah Desa Saribaye sebaiknya menyediakan satu lokasi khusus untuk dijadikan Kampoeng Madu yang dapat menjadi sentra agrowisata yang menarik.
3. Kepada pemerintah kecamatan dengan bekerjasama dengan institusi lain diharapkan terus berupaya memberikan bantuan untuk mengembangkan budidaya madu trigona untuk meningkatkan perekonomian desa agar dapat menjadi desa mandiri.

\section{Ucapan Terima Kasih}

Penulis mengucapkan terima kasih kepada Universitas Mataram yang telah memberika dana untuk kegiatan pengabdian ini.

\section{Daftar Pustaka}

Corlett, R. T (2011). Honeybees in natural ecosystems. Honeybees of Asia. R. Hepburn and Sarah E. Radolf (Eds). Springer, Berlin Heidelberg.

Mutmainnah, M., Hapid, A., dan Hamka, H. (2018). PKM Kelompok Tani Aren di Sekitar KPH Tinombo Dampelas Sulawesi Tengah. Abditani, Vol. 1: 58-64

Novandra, A dan Widnyana I. (2013). Peluang Pasar Produk Perlebahan Indonesia. Balai Penelitian Teknologi Hasil Hutan Bukan Kayu.

Pamulardi, B. (2006). Pengembangan Agrowisata Berwawasan Lingkungan (Studi Kasus Desa Wisata Tingkir, Salatiga). Tesis, Program Magister Ilmu Lingkungan Program Pascasarjana, Universitas Diponegoro.

Sihombing, D. T. H. 2005. Ilmu Ternak Lebah Madu. Gadjah Mada University Press, Yogyakarta.

Yuni, R., Pebri Hastuti, Roni Afriadi, Putri Sari Silaban (2018). Pengembangan Usaha Ternak Lebah Madu Hutan Nagari Sungai Buluh Nagari Sungai Buluh Timur Kecamatan Batang Anai Kabupaten Padang Pariaman. Jurnal Pengabdian Kepada Masyarakat, Vol. 24(4).

Zulkarnaen, Reza M. (2016). Pengembangan Potensi Ekonomi Desa Melalui Badan Usaha Milik Desa (Bumdes) Pondok Salam Kabupaten Purwakarta. Jurnal Aplikasi Ipteks untuk Masyarakat, Vol. 5(1): 1-4. 